\title{
Analisis indikator makro ekonomi terhadap Jakarta Islamic Index
}

\author{
Dini Rahmayanti ${ }^{*}$ \\ ${ }^{1}$ Fakultas Ekonomi dan Bisnis Islam, IAIN Salatiga, Indonesia \\ ${ }^{*}$ Korespondensi (e-mail: dinirahmayanti10@gmail.com)
}

\begin{abstract}
Stock price fluctuations in various sectors continue to show a decline due to the Covid-19 pandemic. This is due to its nature which is strongly influenced by external changes or fundamental information, in this case the ability of investors to understand will influence investors' decisions to invest. This study aims to determine the effect of macroeconomic indicators on the Jakarta Islamic Index, the observation period 2015-2021 using monthly time series data. Macro indicators used in analyzing the stock of the Jakarta Islamic Index are inflation, interest rates, industrial production growth, crude oil, exchange rates, and the industry average dowjones as global index variables. The analysis technique used is multiple linear regression. Simultaneous test results show that the macro variable indicators and DJIA have a significant effect on JII. The results of the partial test show that inflation and DJIA have a significant positive effect on $\mathrm{JII}$, while the exchange rate and crude oil have a significant positive effect on JII, for the variables of industrial production growth and interest rates have no significant effect on JII.
\end{abstract}

Keywords: JII, Macroeconomics, Global Index

\begin{abstract}
Abstrak
Fluktuasi harga saham diberbagai sektor terus menunjukkan penurunan akibat dari Pandemi covid-19. Hal ini disebabkan sifatnya yang sangat dipengaruhi oleh perubahan eksternal atau informasi fundamental, dalam hal ini kemampuan investor dalam memahami akan mempengaruhi keputusan investor dalam berinvestasi. Penelitian ini bertujuan untuk mengetahui pengaruh dari indikator makro ekonomi terhadap Jakarta Islamic Index, periode pengamatan tahun 2015-2021 dengan menggunakan data time series bulanan. Indikator makro yang digunakan dalam menganalisis saham Jakarta Islamic Index yaitu inflasi, suku bunga, pertumbuhan produksi industri, crude oil, kurs, dan dow jones industrial average sebagai variabel index global. Teknik analisis yang digunakan adalah regresi linier berganda. Hasil uji simultan menunjukkan bahwa indikator variabel makro dan DJIA berpengaruh signifikan terhadap JII. Hasil uji parsial menunjukkan bahwa inflasi dan DJIA berpengaruh positif signifikan terhadap JII, sedangkan kurs dan Crude oil berpengaruh positif signifikan terhadap JII, untuk variabel pertumbuhan produksi industri dan suku bunga tidak berpengaruh secara signifikan terhadap JII.
\end{abstract}

Kata kunci: JII, Makro Ekonomi, Indeks Global

How to cite: Dini, D. R. (2021). Analisis indikator makro ekonomi terhadap Jakarta Islamic Index. Journal of Economics Research and Policy Studies, 1(2), 117-131. https://doi.org/10.53088/jerps.v1i2.234

\section{Pendahuluan}

Pasar modal merupakan salah satu wadah investasi melalui penjualan saham, penerbitan obligasi, selain itu pasar modal juga sebagai indikator stabilitas kondisi 
perekonomian suatu negara dan memiliki peranan yang penting bagi perekonomian suatu negara. Peranan penting tersebut berdasarkan dua fungsi pasar modal, yaitu fungsi ekonomi dan fungsi keuangan. Fungsi ekonomi sebagai sarana bagi perusahaan untuk mendapatkan dana dari masyarakat yaitu pemodal atau investor. Fungsi keuangan pasar modal menawarkan kesempatan memperoleh imbalan (return) bagi para investor (Hidayat, 2019).

Peran pasar modal syariah dalam mendorong perekonomian sangat penting diantaranya dapat memberikan dampak bagi pertumbuhan pasar riil melalui investasi berbasis syariah. Investasi syariah mengintegrasikan nilai-nilai agama yang dianut dalam melakukan investasi dengan cara melakukan seleksi (screening) dalam memilih instrumen investasinya dan dengan cara yang sudah sesuai dengan syariat islam. Tandelilin (2010) menyatakan investor bisa melakukan analisis fundamental secara top-down yang meliputi analisis variabel-variabel makro yang mempengaruhi kinerja seluruh perusahaan.

Jakarta Islamic Indeks merupakan bagian dari pasar modal syariah, sehingga kegiatan usaha dalam sebuah perusahaan harus melalui proses maupun tahapantahapan, yang kemudian dievaluasi secara berkala. Sebagai instrumen ekonomi pasar modal, maka JII tidak terlepas dari pengaruh-pengaruh baik dari faktor ekonomi maupun non ekonomi. Beberapa variabel ekonomi makro yang perlu diperhatikan investor antara lain; Produk Domestik Bruto (PDB), tingkat inflasi, tingkat bunga, kurs mata uang, Anggaran defisit, Investasi swasta, Neraca perdagangan dan pembayaran (Tandelilin, 2010).

Saham merupakan salah satu instrumen investasi yang banyak diminati oleh investor, karena memberikan keuntungan, dapat mengembangkan aset dan tujuan investasi lainnya. Disamping keuntungan, saham juga tentunya memiliki risiko yang harus ditanggung oleh para investor. Pada awal tahun 2020, seluruh dunia digemborkan oleh pandemi covid-19 termasuk di Indonesia, tidak hanya kesehatan masyarakat, namun pandemi ini turut mempengaruhi perekonomian di berbagai penjuru dunia. Tahun 2020 perekonomian di Indonesia tumbuh negatif, angka pengangguran dan kemiskinan meningkat, berdasarkan data pertumbuhan ekonomi year on year pada triwulan pertama tahun 2020 pertumbuhan ekonomi di Indonesia menunjukkan pelemahan, yaitu hanya mencapai 2,97\% dibanding pada tahun 2019 sebesar $5,07 \%$, dilanjutkan pada triwulan kedua tahun 2020 menunjukkan pelemahan sebesar $-5,32 \%$. Awal pandemi hingga saat ini pemerintah terus melakukan pemulihan-pemulihan, berbagai kebijakan ekonomi telah ditetapkan pemerintah, berbagai strategi pemulihan ekonomi nasionalpun tetap dilanjutkan agar pertumbuhan ekonomi meningkat dan roda perekonomian pulih kembali. Termasuk harga saham pada masa pandemi terus mengalami penurunan, fluktuasi harga saham diberbagai sektor terus menunjukkan penurunan akibat dari Pandemi covid-19. Hal ini disebabkan sifatnya yang sangat dipengaruhi oleh perubahan eksternal atau informasi fundamental, seperti pergerakan suku bunga, nilai tukar, perubahan inflasi,. Kondisi perekonomian saat ini, kemampuan investor dalam memahami akan mempengaruhi keputusan investor dalam berinvestasi. 
Secara teoritis, indeks harga saham akan merespon negatif maupun positif terhadap informasi yang diterima. Inflasi, menyebabkan kenaikan biaya secara terus menerus sehingga biaya produksi suatu perusahaan akan meningkat. Ketika terjadi inflasi, maka para investor akan melepas saham untuk menghindari risiko yang tidak pasti, sehingga menyebabkan bursa saham akan turun. Selanjutnya, tingkat bunga menentukan jenis investasi yang akan memberikan keuntungan kepada para investornya. Sesuai dengan teori Keynes, semakin rendah tingkat suku bunga maka akan semakin besar investasinya. Semakin kecil tingkat suku bunga, jika investasi yang didapat dari suku bunga tersebut, investasi akan meningkat.

Produksi industri digunakan sebagai representasi bagi pendapatan nasional untuk menggantikan ketiadaan data PDB dalam bulanan. Pertumbuhan produksi industri yang berarti peningkatan hasil output yang di produksi suatu negara sehingga menjadi sinyal positif bagi para investor. Selain itu, perubahan nilai kurs juga mempengaruhi fluktuasi indeks harga saham suatu negara. Apabila nilai tukar terhadap dollar di sebuah negara meningkat yang akan berdampak pada pemilihan berinvestasi oleh para investor. Investor akan memilih menanamkan modalnya di saham karena akan mendapatkan profit yang lebih, maka kurs merupakan salah satu variabel yang digunakan dalam memprediksi harga saham. Selain itu, DJIA merupakan acuan pergerakan pasar modal Amerika Serikat yang diakui dunia. Berdasarkan teori Contagion Effect, ketika terjadi fluktuasi di salah satu bursa di suau negara, maka akan mempengaruhi keadaan bursa lainnya di seluruh dunia. Oleh karena itu, ketika DJIA mengalami pergerakan, maka akan selalu diikuti pergerakan yang sama pada indeks harga saham di Indonesia. selanjutnya, kenaikan harga minyak dunia merupakan indikator awal perbaikan siklus ekonomi (recovery cycle) sehingga dianggap sebagai good news oleh para investor, begitu juga sebaliknya. Oleh karena itu, perubahan harga minyak akan memberi pengaruh positif terhadap indeks harga saham.

Indikator ekonomi makro merupakan faktor yang tidak bisa diubah, namun perlu dilakukan penyesuaian. Oleh karena itu, para investor harus selalu memantau pergerakan atau perkembangan makro ekonomi suatu negara agar mampu menyesuaikan keadaan yang terjadi dan keputusan yang akan diambil dalam berinvestasi. Dengan mengetahui tanda-tanda tentang keadaan perekonomian atau data indikator-indikator ekonomi dapat dimanfaatkan dalam kaitannya dengan pasar modal sehingga memberikan hasil yang optimal dalam berinvestasi. Penelitian telah dilakukan oleh Desfiandi et al. (2017) variabel tingkat kurs dollar USD/ Rupiah berpengaruh negatif terhadap pergerakan indeks harga saham gabungan (IHSG), sedangkan variabel inflasi dan Dowjones index tidak berpengaruh terhadap indeks harga saham gabungan. Secara simultan, tingkat kurs USD / IDR, inflasi, DJIA, dan IMS mempengaruhi gerakan IHSG.

Dalam penelitian ini, penulis mengembangkan variabel makro ekonomi yaitu inflasi, suku bunga, kurs nilai tukar, pertumbuhan produksi industri, crud oil, serta indeks internasional yaitu Dow Jones Industrial Average. Secara teoritis variabel tersebut memiliki hubungan erat dengan perubahan harga saham di pasar modal, termasuk 
Jakarta Islamic Index, yang beranggotakan 30 saham yang paling liquid dan memiliki nilai kapitasisasi yang sangat besar.

\section{Tinjauan Pustaka}

\section{Investasi}

Investasi adalah suatu komitmen atas sejumlah dana atau sumber daya lainnya yang dilakukan saat ini dengan tujuan memperoleh sejumlah keuntungan di masa datang. Tujuan dari seseorang melakukan investasi adalah untuk 'menghasilkan sejumlah uang' (Tandelilin, 2010). Sejumlah uang tersebut dapat diperoleh dari capital gain dan dividen perusahaan. Investasi ke dalam aktiva keuangan dapat berupa investasi langsung dan investasi tidak langsung. Investasi langsung dapat dilakukan dengan membeli aktiva keuangan yang dapat diperjualbelikan dipasar uang (money market), pasar modal (capital market), atau pasar turunan (derivative market). Invetasi tidak langsung dilakukan dengan membeli surat-surat berharga dari perusahaan investasi.

\section{Contagion Effect theory}

Contagion effect juga disebut dengan efek domino atau efek tular. Contagion effect merupakan salah satu dampak negatif di samping keuntungan yang muncul adanya integrasi pasar modal internasional. Menurut Widiyanti, teori domino adalah fenomena perubahan berantai berdasarkan prinsip geo-politik dan geo-strategis. Dengan adanya crash di salah satu bursa seperti yang terjadi pada indeks Dow Jones akan mengakibatkan crash juga pada bursa-bursa di seluruh dunia (Atmadjaja, 1999). Begitu pula dengan Jakarta Islamic Index, ketika terjadi sesuatu pada dow jones industrial average, hal itu akan menular kepada Jakarta Islamic Index sesuai dengan contagion effect theory.

\section{Random Walk Theory}

Menurut Samsul, harga saham bergerak secara acak berarti bahwa fluktuasi harga saham bergantung pada informasi yang akan diterima tetapi informasi tersebut tidak diketahui kapan akan diterimanya sehingga informasi baru dan harga saham itu disebut unpredictable (Muhammad, 2006). Informasi tersebut bersifat berita buruk (bad news) atau berita baik (good news) juga tidak diketahui. Apabila sudah diketahui maka informasi itu disebut informasi sekarang. Berita buruk berarti bahwa informasi akan berdampak negatif terhadap harga saham, yaitu penurunan harga saham. Berita baik berarti informasi akan berdanpak positif terhadap harga saham yaitu kenaikan harga saham.

\section{Inflasi}

Inflasi adalah suatu proses meningkatnya harga-harga secara umum dan terus menerus dengan mekanisme pasar yang disebabkan oleh berbagai faktor, seperti konsumsi masyarakat yang meningkat, kelebihan likuiditas yang memicu spekulasi, hingga adanya ketidaklancaran distribusi barang (Wardiyah, 2017). Inflasi meningkatkan beban perusahaan. Jika peningkatan biaya produksi lebih tinggi dari peningkatan harga yang dapat dinikmati oleh perusahaan maka profitabilitas perusahaan akan turun. Hal ini berdampak menurunnya investasi, termasuk investasi 
pada pasar modal yaitu pada saham, sehingga inflasi memiliki hubungan yang negatif terhadap pergerakan harga saham (JII).

\section{Suku Bunga}

Tingkat suku bunga merupakan salah satu indikator dalam menentukan apakah seseorang akan melakukan investasi atau menabung (Boediono, 1994). Secara teoritis perubahan tingkat bunga secara langsung merubah discount rate dan mempengaruhi arus kas perusahaan saat ini dan masa depan. Tingkat bunga yang tinggi merupakan sinyal negatif terhadap harga saham, peningkatan tingkat bunga mungkin menyebabkan investor menarik investasinya pada saham dan memindahkannya pada instrumen investasi yang lain. Secara umum dapat dikatakan bahwa semakin rendah tingkat suku bunga, maka pertumbuhan ekonomi meningkat karena intensitas aliran dana akan meningkat. Jika suku bunga tinggi, otomatis orang akan lebih memilih untuk menyimpan dana mereka di bank karena mereka dapat mengharapkan pengembalian yang menguntungkan. Dan dalam posisi ini, permintaan masyarakat untuk memegang uang tunai lebih rendah karena mereka sibuk mengalokasikannya ke dalam portofolio perbankan (deposito dan tabungan) (Jefry \& Djazuli, 2020). Dengan demikian, Sukubunga memiliki pengaruh negatif terhadap harga saham di Jakarta Islamic Index.

\section{Kurs Nilai Tukar}

Kurs merupakan perbandingan nilai mata uang domestik dengan nilai mata uang negara lain. Jika diformulasikan kurs domestik terhadap dollar misalnya rupiah yang diperlukan untuk membeli satu dollar. Apabila kurs rupiah meningkat artinya rupiah mengalami depresiasi (melemah) sedangkan jika kurs rupiah menurun artinya rupiah mengalami apresiasi (menguat). Nilai kurs domestik terhadap dolar menjadi hal penting bagi perusahaan yang melakukan kegiatan ekspor dan impor (Khan, 2019). Jika nilai rupiah mengalami depresiasi akan membuat harga barang impor naik dan biaya perusahaan yang menggunakan bahan baku impor akan mengalami kenaikan yang berimbas pada turunnya keuntungan. Oleh karena itu, nilai tukar yang melemah akan menurunkan minat investor dalam berinvestasi saham dan menurunkan harga saham.

\section{Pertumbuhan Produksi Industri}

Pertumbuhan ekonomi merupakan salah satu indikator yang sangat penting dalam melakukan analisis tentang pembangunan ekonomi yang terjadi pada suatu negara, kenaikan jangka panjang dalam kemampuan suatu negara untuk menyediakan semakin banyak jenis barang-barang ekonomi kepada penduduknya, kemampuan tersebut tumbuh ssesuai dengan kemajuan teknologi dan penyesuaian kelembagaan serta ideologis yang dilakukan. Meningkatnya PDB merupakan sinyal yang baik (positif) untuk investasi dan sebaliknya. Meningkatkan PDB mempunyai pengaruh positif terhadap daya beli konsumen sehingga dapat meningkatkan permintaan terhadap produk perusahaan. Peningkatan permintaan terhadap produk perusahaan akan meningkatkan profit dan akhirnya akan meningkatkan harga saham perusahaan. 
Dengan hal tersebut, proxy pertumbuhan ekonomi dalam penelitian ini menggunakan perkembangan produksi industri, dimana produksi industri merupakan total produksi dari keseluruhan pabrik, pertambangan, perusahaan pelayanan publik, produksi manufaktur. Tingkat pertumbuhan produksi industri, suatu determinan harga saham dimasa yang akan datang, pertumbuhan pada aktivitas riil sebagai tanda bahwa adanya peningkatan pada arus kas perusahaan dimassa yang akan datang ditandai dengan adanya peningkatan output. (Chen dan Schwert dalam Ming Hua Liu), dengan demikian produksi industri merupakan suatu variabel yang berpengaruh positif terhadap harga saham.

\section{Harga Minyak Dunia (Crude Oil Price)}

Harga minyak dunia merupakan indikator yang memegang peran penting dalam perekonomian suatu negara termasuk di Indonesia, karena minyak mentah sangat dibutuhkan untuk melakukan aktivitas ekonomi. Fluktuasi harga minyak mentah dunia Secara tidak langsung meningkatkan harga minyak mentah dunia maka akan berimbas pada sektor ekspor dan impor suatu Negara. Pengaruh Harga Minyak Dunia Terhadap Return Saham Minyak mentah atau yang juga dikenal sebagai Crude Oil merupakan komoditas dan kebutuhan utama dunia saat ini. Investor pasar modal menganggap bahwa naiknya harga minyak mentah dunia merupakan pertanda meningkatnya permintaan, yang mengindikasi membaiknya ekonomi global paska krisis. jika harga minyak mentah meningkat, ekspektasi terhadap kinerja perusahaanperusahaan juga akan meningkat dan otomatis harga sahamnya akan ikut terkerek naik yang di ikuti kenaikan return saham sektor pertambangan (Hanoeboen, 2017).

\section{Dow Jones Industrial Average}

Indeks Dow Jones Industrial Average adalah rata-rata tertimbang harga 30 saham blue-chip yang umumnya para pemimpin dalam industri mereka. Ini telah menjadi indikator luas diikuti dari pasar saham sejak 1 Oktober 1928 (Bloomberg, 2021). DJIA pada awal berdirinya hanya terdiri dari 12 saham dari berbagai industri penting di Amerika Serikat. Sekarang ini pemilihan daftar perusahaan yang berhak tercatat dalam DJIA dilakukan oleh editor dari Wall Street Journal. Pemilihan ini didasarkan pada kemampuan perusahaan, aktivitas ekonomi, pertumbuhan laba dan lain-lain. Perusahaan yang dipilih pada umumnya adalah perusahaan Amerika yang kegiatan ekonominya telah mendunia.

M. Samsul dalam Witjaksono (2010) mengungkapkan bahwa pergerakan indeks di pasar modal suatu negara dipengaruhi oleh indeks-indeks pasar modal dunia. Hal ini disebabkan aliran perdagangan antar negara, adanya kebebasan aliran informasi, serta deregulasi peraturan pasar modal yang menyebabkan investor semakin mudah untuk masuk di pasar modal suatu negara. Hal ini juga menggunakan teori contagion effect yang menyebutkan bahwa bila terjadi crash di salah satu bursa seperti yang terjadi pada indeks Dow Jones akan mengakibatkan crash juga pada bursa-bursa di seluruh dunia, termasuk JII. 


\section{Metode Penelitian}

\section{Jenis dan Populasi Penelitian}

Data yang digunakan dalam penelitian ini merupakan data sekunder, penelitian kuantitatif yang meliputi data inflasi, suku bunga, indeks produksi industri, kurs mata uang, harga crude iol, dan dow jones industrial average index, serta harga saham di Jakarta Islamic Index sebagai populasi dan sampel.

Data sekunder variabel makro data diambil dari biro pusat statistik dan, data indeks harga saham dan indeks saham global diperoleh dari yahoo.finance.com, untuk data antar waktu (time series) diambil pada bulan ke 1 tahun 2014 sampai bulan ke 12 tahun 2021 dimana data ini merupakan data yang dikumpulkan dalam kurun waktu tertentu dari sampel.

\section{Metode Analisis}

Dalam Penelitian ini menggunakan metode analisis regresi linier berganda dan sebagai alat dalam pengolahan datanya yaitu menggunakan bantuan program Eviews. Estimasi model regresi menggunakan Metode Regesi Linier Berganda

Model Regresi:

$$
\begin{aligned}
& J I I=\beta_{0}+\beta_{1} \text { Inflasi }+\beta 2 S B+\beta_{3} P P I+\beta_{4} \text { Kurs }+\beta_{5} C O+\beta_{6} D J I A+e \\
& \text { Keterangan: } \\
& \text { JII : Variabel dependen (Jakarta Islamic Index) } \\
& \text { } \beta 0 \text { : konstanta } \\
& \beta 1-, \beta 5 \text { : koefisien variabel independen } \\
& \text { Inflasi : Tingkat inflasi } \\
& \text { SB : Tingkat suku bunga } \\
& \text { PPI : Pertumbuhan Produksi Industri } \\
& \text { Kurs : Kurs mata uang terhadap dolar } \\
& \text { CO : Crude Oil } \\
& \text { DJIA : DowJones Industrial Average } \\
& \text { e : error }
\end{aligned}
$$

\section{Uji Asumsi Klasik}

Persamaan regresi yang baik harus bersifat BLUE (Best Linear Unbiased Estimator), artinya pengambilan keputusan melalui uji $\mathrm{F}$ dan uji t tidak boleh bias. Uji ini untuk melihat layak atau tidaknya model regresi yang digunakan untuk memprediksi variabel terikat berdasarkan masukan variabel bebasnya, maka model regresi harus terbebas dari beberapa asumsi klasik (Uji normalitas, uji autokorelasi, uji heteroskedastisitas, uji multikolinearitas).

\section{Hasil dan Pembahasan}

\subsection{Hasil penelitian}

\section{Uji Pemilihan Model Terestimasi}

Uji normalitas bertujuan untuk menguji apakah variabel bebas memiliki distribusi normal atau tidak dalam model regresi. Suatu model regresi yang baik adalah apabila 
keduanya memiliki distribusi normal atau mendekati normal. Hasil uji normalitas dengan Jarque-Berra menunjukkan bahwa nilai residual berdistribusi normal, sehingga analisis regresi dapat terpenuhi. Dapat diketahui Probability yaitu 0,064 > $5 \%$, maka dapat diambil kesimpulan bahwa data berdistribusi normal.

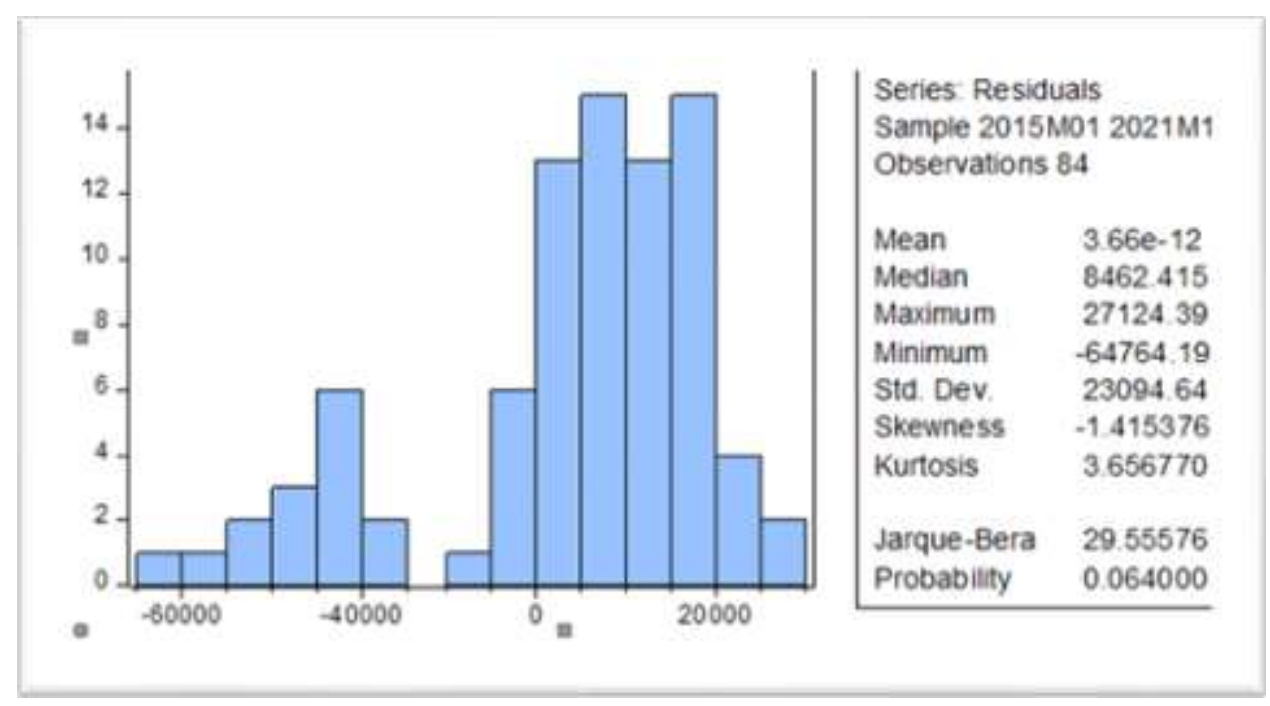

Gambar 1. Uji Normalitas

\section{Uji Multikolinearitas}

Uji multikolinearitas bertujuan untuk menguji apakah dalam model regresi terdapat korelasi antarvariabel bebas. Untuk dapat mengetahui terjadi atau tidaknya multikolinieritas dalam model regresi adalah dengan melihat nilai tolerance dan variance inflation factor (VIF). Multikolinieritas terjadi apabila nilai VIF > 10 dan jika tolerance $<0,10$. pada Tabel 1 dapat dilihat nilai VIF dan tolerance untuk setiap variabel dalam penelitian.

Tabel 1. Uji Multikolinieritas

\begin{tabular}{cccc}
\hline Variable & $\begin{array}{c}\text { Coefficient } \\
\text { Variance }\end{array}$ & $\begin{array}{c}\text { Uncentered } \\
\text { VIF }\end{array}$ & $\begin{array}{c}\text { Centered } \\
\text { VIF }\end{array}$ \\
\hline C & $1,41 \mathrm{E}+09$ & 242,1457 & NA \\
I & 11713932 & 27,56753 & 4,832467 \\
SB & 12767768 & 63,51814 & 3,609715 \\
KURS & 2,339318 & 77,15394 & 1,061823 \\
PPI & 801885,9 & 2,966896 & 1,137859 \\
CO & 76658,32 & 40,12554 & 2,051609 \\
DJIA & 0,880547 & 93,87375 & 4,565750 \\
\hline
\end{tabular}

Berdasarkan Tabel 1 dapat dilihat nilai VIF pada masing-masing variabel yaitu Inflasi sebesar 4,832467, Suku bunga sebesar 3,609715, kurs 1,061823, PPI sebesar 1,137859, Crude oil 2,051609 dan DowJones Industrial Average sebesar 4,565750. Nilai VIF dari ke enam variabel tidak ada yang lebih besar dari 10. Maka dapat dikatakan tidak terjadi multikolinieritas pada keenam variabel tersebut.

\section{Uji Autokorelasi}

Adapun hasil pengujian uji autokorelasi yang ditunjukkan pada Tabel 2. 
Tabel 2. Uji Autokorelasi

\begin{tabular}{crlr}
\hline F-statistic & 0,097386 & Prob. F(2,75) & 0,9073 \\
\hline Obs*R-squared $^{*}$ & 0,217580 & Prob. Chi-Square(2) & 0,8969 \\
\hline
\end{tabular}

Pada penelitian ini uji autokorelasi dilakukan menggunakan uji Breusch-Godfrey dengan cara melihat nilai probability dari Obs* ${ }^{*}$-squared dengan tingkat signifikansi sebesar 0,05 . Apabila nilai probability $\mathrm{Obs}^{*} \mathrm{R}$-Squared pada penelitian lebih besar dari 0,05 maka dapat disimpulkan bahwa data terbebas dari autokorelasi. Berdasarkan hasil pengujian yang ditunjukkan oleh Tabel 2 diketahui bahwa nilai probability dari Obs*R-squared sebesar 0,8969 yang nilainya lebih besar dari 0,05 maka dapat disimpulkan bahwa penelitian ini terbebas dari autokorelasi.

\section{Uji Heteroskedastisitas}

Pengujian heteroskedastisitas dalam penelitian ini dilakukan dengan uji white. Ada atau tidaknya heteroskedastisitas dapat diketahui dari nilai probabilitas $\mathrm{Obs}^{\star} \mathrm{R}$-Square yang nantinya akan dibandingkan dengan tingkat signifikansi. Jika nilai probabilitas signifikansinya diatas 0,05 maka dapat disimpulkan tidak terjadi heteroskedastisitas. Adapun hasil pengujian uji heteroskedastisitas yang ditunjukkan pada Tabel 3 .

Tabel 3. Uji Heteroskedastisitas

\begin{tabular}{llll}
\hline F-statistic & 1,228859 & Prob. F(27,56) & 0,2534 \\
\hline Obs*R-squared & 31,25227 & Prob. Chi-Square(27) & 0,2609 \\
Scaled explained SS & 29,54461 & Prob. Chi-Square(27) & 0,3350
\end{tabular}

Berdasarkan hasil pengujian yang ditunjukkan pada Tabel 3, dapat diketahui bahwa nilai probabilitas $\mathrm{Obs}^{*} \mathrm{R}$-Square sebesar 0,2609 . Hal ini sesuai dengan kriteria pengujian uji white bahwa memiliki nilai probabilitas $\mathrm{Obs}^{*} \mathrm{R}-\mathrm{Square}$ lebih besar daripada signifikansi $(0,2609>0,05)$. Maka dapat disimpulkan bahwa data tidak memiliki masalah heteroskedasiitas sebab sesuai dengan ketetapan melebihi tingkat signifikan.

\section{Hasil Analisis Multivariat (Regresi Linier Berganda)}

Analisis regresi berganda digunakan untuk mengetahui pengaruh indikator makro ekonomi yaitu ; inflasi, suku bunga, kurs, PPI, crude oil, DJIA terhadap Jakarta Islamic index pada tahun 2015-2021. Berdasarkan perhitungan yang dilakukan dengan program Eviews yaitu sebagai berikut:

Tabel 4. Hasil Estimasi Output

\begin{tabular}{crrrr}
\hline Variable & Coefficient Std. Error & t-Statistic & Prob. \\
\hline C & 87937,69 & 37349,58 & 2,354449 & 0,0211 \\
I & $-8958,200$ & 3454,087 & $-2,593508$ & 0,0114 \\
SB & $-1802,994$ & 3552,514 & $-0,507526$ & 0,6133 \\
KURS & 3,474742 & 1,523105 & 2,281354 & 0,0253 \\
PPI & 631,0900 & 889,9798 & 0,709106 & 0,4804 \\
CO & 1043,758 & 275,8364 & 3,783975 & 0,0003 \\
DJIA & $-4,137700$ & 0,938929 & $-4,404700$ & 0,0000 \\
\hline R-squared & $0,253897 F-s t a t i s t i c$ & & 4,310433 \\
Adjusted R-squared & 0,194994Prob(F-statistic) & 0,000857 \\
\hline
\end{tabular}


$\mathrm{JII}=87937,69+(-8958,200 \mathrm{X} 1)+(-1802,994 \mathrm{X} 2)+3,474742 \mathrm{X} 3+631,0900 \mathrm{X} 4$ $+1043.758 \times 5+(-4,137500 \times 6)$

Berdasarkan persamaan diatas diperoleh nilai koefisiennya yaitu 87937,69. Hal ini berarti bahwa dengan adanya inflasi, suku bunga, kurs, PPI, Co dan DJIA nilai konstan saham JII sebesar 87937,69. Koefisien regresi variabel inflasi sebesar -8958,2 artinya bahwa peningkatan $1 \%$ variabel inflasi dengan asumsi variabel bebas lain konstan akan menyebabkan penurunan saham JII sebesar 8958,2. Koefisien regresi variabel suku bunga sebesar $-1802,994$ artinya bahwa peningkatan $1 \%$ variabel suku bunga dengan asumsi variabel bebas lain konstan akan menyebabkan penurunan saham JII sebesar 1802,994, demikian sebaliknya, jika penurunan inflasi ataupun suku bunga sebesar $1 \%$ menyebabkan peningkatan saham JII sebesar masing-masing koefisien.

Koefisien regresi variabel kurs sebesar 3,474742 , artinya bahwa peningkatan $1 \%$ variabel inflasi dengan asumsi variabel bebas lain konstan akan menyebabkan peningkatan saham JII sebesar 3,474742. Demikian sebaliknya, jika penurunan kurs sebesar $1 \%$ menyebabkan penurunan saham JII sebesar masing-masing koefisien.

Koefisien regresi variabel pertumbuhan produksi industri sebesar 631,0900, artinya bahwa peningkatan $1 \%$ variabel PPI dengan asumsi variabel bebas lain konstan akan menyebabkan peningkatan saham JII sebesar 631,0900. Demikian sebaliknya, jika penurunan PPI sebesar 1\% menyebabkan penurunan saham JII sebesar 631,0900.

Koefisien regresi variabel Crude oil sebesar 1043,758, artinya bahwa peningkatan $1 \%$ variabel $\mathrm{CO}$ dengan asumsi variabel bebas lain konstan akan menyebabkan peningkatan saham JII sebesar 1043,758. Demikian sebaliknya, jika penurunan CO sebesar 1\% menyebabkan penurunan saham JII sebesar 1043,758.

Koefisien regresi variabel Dowjones Industrial Average sebesar $-4,137500$, artinya bahwa peningkatan $1 \%$ variabel DJIA dengan asumsi variabel bebas lain konstan akan menyebabkan penurunan saham JII sebesar 4,137500. Demikian sebaliknya, jika penurunan DJIA sebesar 1\% menyebabkan peningkatan saham JII sebesar 4,137500.

\section{Pengujian pengaruh simultan dengan Uji F}

Pengaruh variabel independen secara simultan terhadap variabel dependen dianalisis dengan menggunakan uji $\mathrm{F}$, yaitu dengan memperhatikan signifikansi nilai $\mathrm{F}$ tingkat alpha sebesar 5\%. Pada Tabel 4 menunukkan nilai uji $F$ sebesar 4,310433 dengan nilai probabilitas 0,000857 , nilai signifikansi $F$ lebih kecil dari $5 \%$, dengan demikian dapat diambil kesimpulan bajwa semua variabel independen dalam penelitian ini secara bersama-sama atau simultan berpengaruh terhadap saham Jakarta Islamic Index. Hal demikian berarti jika inflasi, suku bunga, PPI, kurs, Co, DJIA mengalami kenaikan maka akan memberikan perubahan pada saham JII.

\section{Analisis koefisien Determinasi $\left(R^{2}\right)$}

Koefisien determinasi menjelaskan variasi pengaruh variabel-variabel bebas terhadap variabel terikatnya. Nilai koefisien determinasi dapat diukur oleh nilai R-Square atau Adjusted R-Square. Besarnya koefisien determinasi $\left(R^{2}\right)$ pada penelitian ini yaitu sebesar 0,253897 atau $25,38 \%$, sehingga dapat dikatakan bahwa $25,38 \%$ variabel 
terikat yaitu Jakarta Islamic Index pada model dapat dijelaskan oleh variabel bebas yaitu inflasi, suku bunga, PPI, kurs, Crude oil, DJIA sedangkan sisanya $74,62 \%$ dipengaruhi oleh variabel lain diluar model.

\section{Analisis Pengaruh Parsial dengan Uji t}

Uji parsial (uji t) digunakan untuk mengetahui apakah model persamaan regresi telah signifikan untuk digunakan mengukur pengaruh secara parsial variabel bebas (inflasi, suku bunga, PPI, kurs, Crude oil, DJIA) terhadap Jakarta islamic index. Dari hasil pengolahan data dengan menggunakan program eviews diperoleh hasil output sebagai berikut :

Tabel 5. Uji $\mathrm{t}$

\begin{tabular}{|c|c|c|}
\hline Variable & t-Statistic & Prob. \\
\hline $\mathrm{C}$ & 2,354449 & 0,0211 \\
\hline I & $-2,593508$ & 0,0114 \\
\hline SB & $-0,507526$ & 0,6133 \\
\hline KURS & 2,281354 & 0,0253 \\
\hline PPI & 0,709106 & 0,4804 \\
\hline $\mathrm{CO}$ & 3,783975 & 0,0003 \\
\hline DJIA & $-4,404700$ & 0,0000 \\
\hline
\end{tabular}

Nilai probabilitas lebih kecil dari tingkat kesalahan/error 5\%, maka dapat dikatakan bahwa variabel bebas berpengaruh signifikan terhadap variabel terikat, sedangkan apabila nilai probabilitas lebih besar dari tingkat kesalahan/error dengan alpha $5 \%$ maka dapat dikatakan bahwa variabel bebas tidak berpengaruh signifikan terhadap variabel terikat.

Nilai probabilitas dari variabel inflasi sebesar $0,0114<0,05$ sehingga variabel inflasi berpengaruh signifikan terhadap Jakarta Islamic Index. Nilai probabilitas variabel kurs sebesar 0,0253<0,05 sehingga variabel kurs berpengaruh signifikan terhadap Jakarta Islamic Index. Nilai probabilitas variabel Crude oil sebesar 0,0003 0,05 sehingga variabel crude oil berpengaruh signifikan terhadap Jakarta Islamic Index. selanjutnya, nilai probabilitas DowJones Industrial Average sebesar 0,0000<0,05 sehingga variabel DJIA berpengaruh signifikan terhadap Jakarta Islamic Index.

Nilai Probabilitas untuk variabel suku bunga dan pertumbuan produksi industri adalah 0,6133 dan 0.4804 , dimana probabilias tersebut $>0,05$ sehingga variabel suku bunga dan pertumbuhan produksi industri tidak memiliki pengaruh yang signifikan terhadap Jakarta Islamic Index.

\subsection{Pembahasan}

\section{Inflasi terhadap Jakarta Islamic Index}

Koefisien variabel dari Inflasi adalah $-8958,2$ dan probabilitasnya sebesar 0,0221. Ini berarti secara statistik menunjukan bahwa variabel inflasi berpengaruh negatif signifikan terhadap variabel Jakarta Islamic Index. artinya, apabila terjadi peningkatan pada inflasi maka akan menurunkan harga saham. Inflasi merupakan peristiwa moneter yang menunjukkan naiknya harga-harga secara terus menerus, sehingga akan meningkatkan biaya produksi dan beban pada perusahaan. Dengan demikian 
peningkatan biaya produksi lebih tinggi dari peningkatan harga yang dapat dinikmati oleh perusahaan maka profitabilitas perusahaan akan turun kemudian akan mempengaruhi harga saham JII yang bergerak menurun. Dari hasil regres ditemukan bahwa inflasi berpengaruh negatif signifikan terhadap JII. Artinya, setiap kenaikan inflasi akan berpengaruh terhadap JII. Hasil ini membuktikan adanya pengaruh negatif yang signifikan bahwa inflasi digunakan investor sebagai salah satu indikator untuk membeli saham dan juga untuk melepas saham. Sesuai dengan random walk theory dimana harga saham bergerak secara acak, fluktuasi harga saham bergantung pada informasi yang akan diterima. Dari hasil penelitian yang negatif signifikan, investor merespon inflasi sebagai informasi yang buruk (bad news) sehingga berdampak pada penurunan harga saham dan menurunkan profit yang diterima investor. Hasil penelitian ini berbeda dengan penelitian Putu bahwa inflasi tidak memiliki pengaruh yang signifikan (Asmara \& Suarjaya, 2018).

\section{Suku bunga terhadap Jakarta Islamic Index}

Koefisien variabel dari suku bunga adalah -8958,2 dan probabilitasnya sebesar 0,6133. Ini berarti secara statistik menunjukan bahwa variabel suku bunga tidak berpengaruh signifikan terhadap Jakarta Islamic Index. Tingkat bunga merupakan suatu variabel penting yang mempengaruhi masyarakat dalam memilih bentuk kekayaan yang ingin dimilikinya, apakah dalam bentuk uang, financial assets, atau benda-benda riil seperti tanah, rumah, mesin, barang dagangan, dan lain sebagainya. Mana yang memberikan tingkat bunga lebih tinggi akan lebih diminati. Konsisten dengan penelitian yang dilakukan oleh Emta dkk bahwa variabel suku bunga lemah dalam memprediksi volatilitas harga saham (Surbakti et al., 2016), demikian pula pada penelitian ini yang menunjukkan hasil bahwa suku bunga tidak berpengaruh signifikan saham JII, diindikasikan bahwa investor tidak melihat indikator suku bunga sebagai keputusan dalam berinvetasi.

\section{Kurs terhadap Jakarta Islamic Index}

Koefisien variabel dari kurs adalah 3,474 dan probabilitasnya sebesar 0,0253 . Ini berarti secara statistik menunjukan bahwa variabel kurs berpengaruh positif signifikan terhadap Jakarta Islamic Index. Apabila kurs rupiah meningkat artinya rupiah mengalami depresiasi (melemah) sedangkan jika kurs rupiah menurun artinya rupiah mengalami apresiasi (menguat). Nilai kurs domestik terhadap dolar menjadi hal penting bagi perusahaan yang melakukan kegiatan ekspor dan impor. Jika nilai rupiah mengalami depresiasi akan membuat harga barang impor naik dan biaya perusahaan yang menggunakan bahan baku impor akan mengalami kenaikan yang berimbas pada turunnya keuntungan.

Dari hasil tersebut diindikasikan bahwa apabila terjadi pelemahan kurs akan berakibat pada jumlah ekspor atau jasa yang berkurang, sehingga terjadi penurunan pada dividen yang akan diterima pemegang saham, selanjutnya akan berdampak pada keputusan investor untuk melepas sahamnya. Namun, Kurs melemah di anggap sinyal positif oleh investor asing, karena bisa membeli saham dengan harga rendah. Selain itu, exchange rate tergantung pada tingkat perdagangan internasional dan transaksi perdagangan suatu negara atau hubungan nilai tukar dengan JII tergantung 
pada dominasi relatif ekspor dan tingkat impor suatu Negara. Sejalan dengan penelitian yang dilakukan oleh Nordin dkk yang menyatakan bahwa kurs nilai tukar berpengaruh terhadap kinerja pasar saham Malaysia (Nordin et al., 2020).

\section{Pertumbuhan Produksi Industri (PPI) terhadap Jakarta Islamic Index}

Koefisien variabel dari PPI adalah 631,09 dan probabilitasnya sebesar 0,48043. Ini berarti secara statistik menunjukan bahwa variabel Pertumbuhan Produksi Industri tidak berpengaruh signifikan terhadap Jakarta Islamic Index. Badan Pusat Statistik hanya mencatat kegiatan ekonomi formal sebagai perhitungan tingkat PDB Indonesia sehingga angka PDB di Indonesia belum bisa menunjukan semua aktivitas perekonomian di Indonesia. Kelemahan administrasi menjadi penyebab keterbatasan pencatatan kegiatan informal di negara berkembang, struktur kegiatan ekonomi di Indonesia yang didominasi oleh kegiatan informal dan pertanian juga menjadi penyebab keterbatasan kemampuan pencatatan sehingga ketika PDB meningkat belum tentu pendapatan perkapita setiap individu meningkat sehingga pola investasi dipasar modal tidak berpengaruh oleh adanya peningkatan PDB (Asmara \& Suarjaya, 2018). Sejalan dengan hasil penelitian bahwa Pertumbuhan Produksi Industri belum tentu pendapatan meningkat, karena banyak penduduk Indonesia memiliki pengahasilan dari kegiatan informal ataupun kegiatan yang tidak termasuk perhitungan PPI, sehingga PPI belum memberikan pengaruh yang signifikan terhadap saham JII.

\section{Crude Oil terhadap Jakarta Islamic Index}

Koefisien variabel dari crude oil adalah 1043,758 dan probabilitasnya sebesar 0,0003. Ini berarti secara statistik menunjukan bahwa variabel crude oil berpengaruh positif signifikan terhadap Jakarta Islamic Index. Hasil penelitian dari (Hanoeboen, 2017) Investor pasar modal menganggap bahwa naiknya harga minyak mentah dunia merupakan pertanda meningkatnya permintaan, yang mengindikasi membaiknya ekonomi global paska krisis. jika harga minyak mentah meningkat, ekspektasi terhadap kinerja perusahaan-perusahaan juga akan meningkat dan otomatis harga sahamnya akan ikut terkerek naik yang di ikuti kenaikan return saham sektor pertambangan. Sejalan dengan hasil dari penelitian Hanoeboen, Crude Oil memiliki pengaruh positif signifikan terhadap saham JII.

\section{Dowjones Industrial Average terhadap Jakarta Islamic Index}

Koefisien variabel dari Dowjones Industrial Average adalah $-4,137700$ dan probabilitasnya sebesar 0,0000. Ini berarti secara statistik menunjukan bahwa variabel Dowjones Industrial Average berpengaruh negatif signifikan terhadap saham JII. DJIA termasuk indeks terbesar di dunia dan mengalami perkembangan yang cukup pesat, sehingga akan mempengaruhi bursa lain. Pada penelitian ini, terbukti bahwa DJIA memiliki pengaruh yang signifikan, artinya sesuai dengan teori Contagion effect yang menyatakan bahwa terjadinya fluktuasi di salah satu bursa, maka akan mempengaruhi keadaan bursa di seluruh dunia. Crash yang terjadi mempengaruhi crash pada saham JII di Indonesia, hasil yang negatif signifikan diindikasikan bahwa investor asing melihat bahwa DJIA yang meningkat merupakan sinyal positif untuk berinvestasi dikawasan Amerika di banding saham JII. Hal ini berbeda dengan penelitian yang 
dilakukan oleh Adi Mursalin menunjukkan hasil bahwa DJIA tidak berpengaruh terhadap IHSG (Mursalin et al., 2017).

\section{Kesimpulan}

Variabel inflasi dan Dowjones Industrial Average berpengaruh negatif signifikan terhadap JII secara statistik pada periode pangamatan 2015 - 2021. Dengan demikian, ketika inflasi dan Dowjones Industrial Average meningkat, maka saham JII akan merespon negatif dengan mengalami penurunan, begitu juga sebaliknya. Variabel kurs dan crude oil secara statistik berpengaruh positif signifikan terhadap JII secara statistik pada periode pangamatan 2015 - 2021. Dengan demikian, ketika kurs naik (artinya rupiah melemah) akan meningkatkan saham JII dan crude oil mengalami kenaikan, maka akan diikuti oleh peningkatan saham JII, begitupun sebaliknya. Variabel Pertumbuhan Produksi Industri dan Suku bunga hasil penelitian menunjukkan tidak adanya pengaruh yang signifikan pada periode pengamatan tahun 2015-2021.

Dalam penelitian ini dihadapi beberapa keterbatasan yang perlu menjadi perhatian pada penelitian-penelitian yang akan dilakukan selanjutnya. Yaitu, penelitian ini hanya menggunakan variabel inflasi, suku bunga, kurs, pertumbuhan produksi industri, harga minyak mentah sebagai variabel makro ekonomi serta DJIA sebagai indeks global. Penelitian ini tidak melakukan pengujian dengan melihat output jangka pendek dan jangka panjang variabel makro ekonomi dan indeks global terhadap Jakarta Islamic Index.

Bagi para investor sebaiknya dapat mempertimbangkan banyak faktor dalam memutuskan investasi. Fluktuasi dari berbagai variabel makro ekonomi sangat berguna dalam menerapkan strategi perdagangan di pasar modal dan dalam pengambilan keputusan berinvestasi dengan tepat. Untuk peneliti selanjutnya dapat meneliti pengaruh jangka pendek dan jangka panjang variabel makro ekonomi terhadap JII. Penelitian selanjutnya diharapkan dapat meneliti dampak yang diterima saham Jll dari perubahan variabel lain.

\section{Ucapan Terimakasih}

Peneliti mengucapkan banyak terima kasih kepada pihak-pihak yang membantu, terutama civitas akademika Fakultas Ekonomi dan Bisnis Islam IAIN Salatiga yang telah membantu penyelesaian naskah penelitian ini hingga terbit.

\section{Referensi}

Asmara, I. P. W. P., \& Suarjaya, A. A. G. (2018). Pengaruh Variabel Makro Ekonomi Terhadap Indeks Harga Saham Gabungan. 7(3), 1397-1425.

Atmadjaja, Y. V. (1999). Perbandingan Stock Market Crash 1987 dan Stock Market Crash 1997. Bina Ekonomi, 1.

Boediono. (1994). Ekonomi Moneter Seri Sinopsis Pengantar Ilmu Ekonomi Moneter.

Desfiandi, A., Desfiandi, A., \& Ali, H. (2017). Composite Stock Price Index (IHSG) Macro Factor in Investment in Stock (Equity Funds). International Journal of 
Economics

and

Financial

Issues,

$7(3)$

534-536. https://www.econjournals.com/index.php/ijefi/article/view/4841/pdf

Hanoeboen, B. R. (2017). Analisis Pengaruh Harga Minyak Dunia, Nilai Tukar Rupiah, Inflasi Dan Suku Bunga Sbi Terhadap Indeks Harga Saham Gabungan (IHSG). $X I(1)$.

Hidayat, W. W. (2019). Konsep Dasar Investasi dan Pasar Modal. Uwais Inspirasi Indonesia.

Jefry, \& Djazuli, A. (2020). The Effect of Inflation, Interest Rates and Exchange Rates on Stock Prices of Manufacturing Companies in Basic and Chemical Industrial Sectors on the Indonesia Stock Exchange (IDX). International Journal of Business, Management \& Economics Research, 1(1), 34-49. https://doi.org/10.47747/ijbmer.v1i1.49

Khan, M. K. (2019). Impact of Exchange Rate on Stock Returns in Shenzhen Stock Exchange: Analysis Through ARDL Approach. International Journal of Economics and Management, 1(2), 15-26.

Muhammad, S. (2006). Pasar Modal dan Manajemen Portofolio. erlangga.

Mursalin, A., Oktaviani, D., Aisyah, \& Niswan, E. (2017). The Influence of Dollar Exchange Rate, The Dow Jones Index And The Interest Rate Of Bank Indonesia Certificates (SBI) On The Compsite stock Price Index (During The Period Of January 2015 To December 2015). International Journal on Recent Trends in Business and Tourism, 1(2), 69-79.

Nordin, N., Nordin, S., \& Ismail, R. (2020). The Impact of Commodity Prices, Interest Rate and Exchange Rate on Stock Market Performance: An Empirical Analysis From Malaysia. Malaysian Management Journal, 18, 39-52. https://doi.org/10.32890/mmj.18.2014.9015

Surbakti, E. H., Achsani, N. A., \& Maulana, T. N. A. (2016). The Impact of Macroeconomic Variables on JCl's Stock Return Volatility in Pre and Post Global Economic Crisis. International Journal of Scientific and Research Publications, 6(3), 213-220. http://www.ijsrp.org/research-paper-0316/ijsrp-p5136.pdf

Tandelilin, E. (2010). Portofolio dan Investasi Teori dan Aplikasi (edisi pert). Kanisius IKAPI.

Wardiyah, M. L. (2017). Manajemen Pasar Uang \& Pasar Modal (pp. 20-22). Pustaka Setia. 